\title{
Coal ash waste categorisation to determine a regulatory capping profile for coal ash pond rehabilitation
}

\author{
PS Fridell Environmental Resources Management Australia Pty Ltd, Australia \\ C Pearson Environmental Resources Management Australia Pty Ltd, Australia \\ F Woskoboenko HRL Technology Group Pty Ltd, Australia \\ R Brooker ENGIE Australia Pty Ltd, Australia \\ MK Schenkel ENGIE Australia Pty Ltd, Australia
}

\begin{abstract}
The Hazelwood coal mine in the Latrobe Valley, Victoria, Australia ceased operations in March 2017 with the closure of the adjoining Hazelwood Power Station. A water filled void with potential for recreational, agricultural, commercial and industrial uses is envisioned for the surrounding mine licence area following closure. A key step to achieving this is the capping of the coal ash ponds.

At Hazelwood the coal ash ponds (approximately 100 hectares) are licenced as landfills and regulated by the Victorian Environment Protection Authority (EPA). The capping design is therefore required to be approved by the EPA based on waste categorisation as per landfill guidelines. In Victoria there are two dominant risk-based landfill capping types. For higher risk waste (categorised as 'Category C' waste) the EPA requires a composite lined cap consisting of a compacted clay (or geosynthetic clay liner (GCL) equivalent) and a high density polyethylene (HDPE) membrane. For lower risk wastes (categorised as 'Industrial' waste) the EPA permits a compacted clay (or equivalent GCL) only liner without a membrane. To enable EPA to make a risk-based decision, Environmental Resources Management Australia Pty Ltd (ERM) undertook detailed coal ash categorisation considering the Victorian EPA Industrial Waste Resource Guidelines (IWRG) - Solid Industrial Waste Hazard Categorisation and Management' (IWRG631) to satisfy the EPA that the coal ash was a lower risk and that a HDPE liner was not required. The IWRG631 guidelines provide upper total concentrations and leachability limits for waste categories (Category $C$ and Industrial waste) to enable categorisation based on waste characterisation sampling results.

The coal ash (waste) characterisation work included a desk top review of the consistency of the coal ash based on the coal type, power station operational history was undertaken by HRL Technology Group Pty Ltd (HRL) and ERM developed a detailed sampling program. Given the long history of deposition of coal ash deposition (50 years) and thus considerable volume of ash, it was not possible to meet the EPA's volumetric sampling guideline. ERM therefore adopted an innovative statistical approach to determine a reasonable number of samples required to justify the coal ash categorisation.
\end{abstract}

EPA agreed to the approach and ultimately determined a lower risk categorisation enabling the coal ash pond capping to be designed without a HDPE membrane and thus saving ENGIE Australia Pty Ltd (ENGIE) approximately \$15 million in cap construction costs.

Keywords: mine closure, coal ash pond rehabilitation, coal ash pond capping, coal ash analysis, waste categorisation

\section{Introduction}

The Hazelwood coal mine in the Latrobe Valley, Victoria, Australia ceased operations in March 2017 with the closure of the adjoining Hazelwood Power Station which was fuelled by the adjacent Morwell open cut coal mine. The coal ash was a waste product generated by the powerplant which comprised of $8 \times 220 \mathrm{MW}$ 
Babcock and Wilcox Pulverised Fuel Boiler Units, utilising brown coal for the generation of steam. Hazelwood Power Station was approved in 1959 and the first six units commenced service between 1964 and 1971. Two additional generating units were commissioned in 1970 and 1971 respectively.

Coal ash had therefore been deposited in a series of coal ash ponds since the commencement of operations resulting in the accumulation of coal ash in five separate coal ash ponds: four ash ponds denoted as 'Hazelwood Ash Ponds (HAPs)' (HAP1, HAP2, HAP3, HAP4) and one Hazelwood Ash Retention Area (HARA). HAP2 and HAP3 were almost entirely rehabilitated in the early 2000 s and therefore were not considered in the study. The remnant area of HAP2 requiring rehabilitation was denoted as 'HAP2 remnant'. The total area of coal ash pond to be rehabilitated was approximately 100 hectares with an estimated volume of coal ash of 2.5 million $\mathrm{m}^{3}$.

In Victoria, the capping type is reflective of the hazard posed by the waste to the environment; this is determined primarily by total chemical concentrations and leachability, in accordance with Environment Protection Authority (EPA) Victoria Industrial Waste Resource Guideline (IWRG) 631 titled Solid Industrial Waste Hazard Categorisation and Management (IWRG 631) (Environment Protection Authority (EPA) Victoria 2009a). Wastes that pose a lower hazard may be capped with a compacted clay liner (CCL) or geosynthetic clay liner (GCL) only whereas a high risk waste must be capped with composite liner consisting of a CCL (or GCL equivalent) and a high density polyethylene (HDPE) liner in accordance with EPA Publication 788.3 'Best Practice Environmental Management Guideline (BPEM) - Siting, Design, Operation and Rehabilitation of Landfills' (EPA Victoria 2015) (Landfill BPEM).

EPA Victoria requested that sampling of the coal ash for categorisation be undertaken in accordance with EPA IWRG 702 entitled 'Soil sampling' (EPA Victoria 2009b) unless an alternative method was agreed. For volumes of waste greater than $5,000 \mathrm{~m}^{3}$ this publication allowed the determination of a $95 \%$ upper confidence limit (UCLaverage) (95\% upper confidence limit of the average concentration of the sampling results), with a minimum sampling frequency of one sample per $250 \mathrm{~m}^{3}$ of waste. To sample in strict accordance with this EPA guidance required 10,000 samples which was not deemed practical.

Therefore, an alternative approach was proposed to EPA, which was accepted, that was based on demonstrating the consistency of combustion and coal source then utilising an existing limited coal ash dataset. Assuming the ash was normally distributed (assuming consistency in coal mineralogy and combustion), a student's t-distribution was proposed to determine a sample size to provide the best statistical confidence that the results were representative of the coal ash. Samples were then collected from coal ash and analysed to determine a waste categorisation. The mine site and power station are shown in Figure 1.

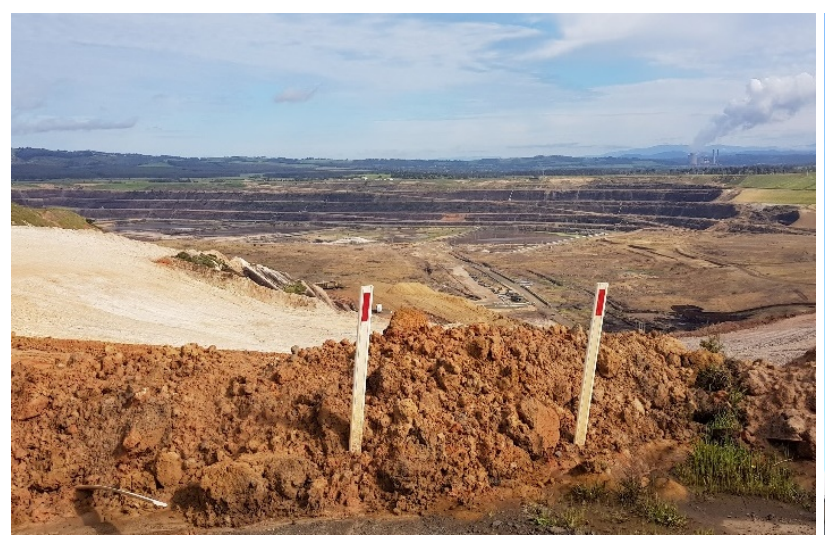

(a)

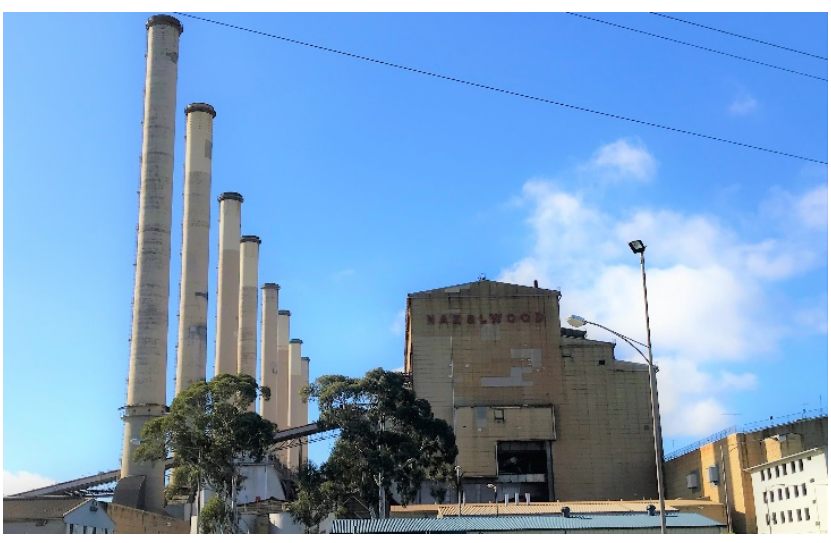

(b)

Figure 1 (a) Morwell open cut coal mine; (b) Hazelwood Power Station 


\section{Coal ash generation \& deposition}

To demonstrate consistency of the coal ash composition over time, HRL Technology Group Pty Ltd (HRL) undertook a review of the coal ash mineralogy, combustion process, coal ash formation and deposition history to validate the assumption that the sampling dataset would be normally distributed.

\subsection{Coal mineralogy}

The main minerals found in Latrobe Valley (LV) coals are sand (quartz, $\mathrm{SiO}_{2}$ ) and various forms of clays (aluminium silicates), such as kaolinite, montmorillonite and others. In terms of coal compositions, these clays can be approximated as one part alumina $\left(\mathrm{Al}_{2} \mathrm{O}_{3}\right)$ and one part silica $\left(\mathrm{SiO}_{2}\right)$, with waters of hydration and hydroxyl forms also present. LV ash is comprised of up to $50 \%$ mineral components.

The levels of sand and clay in LV coal are often higher near the top and base of seams and near inter-seam layers. Small levels of other minerals are often associated with the sand and clay found in LV coal and these levels are often higher when sand and clay levels are high.

The other minerals commonly found are pyrites and marcasite which are iron sulphides $\left(\mathrm{FeS}_{2}\right)$. The levels of $\mathrm{FeS}_{2}$ in LV coal are generally very low, although there are some areas with high organic sulphur content. These high organic sulphur regions are not common in the LV open cut mines, but some areas do exist, often near the base of coal seams. The high organic sulphur regions are believed to be related to the proximity to marine conditions.

Apart from the minerals present in LV coal, most of the other inorganic matter is in the form of salts of carboxylic acids (carboxylates), with common salt $(\mathrm{NaCl})$ also present together with low levels of organically bound $\mathrm{Cl}$. The most prevalent of these inorganic carboxylates are the elements $\mathrm{Ca}, \mathrm{Mg}, \mathrm{Al}, \mathrm{Fe}$ and $\mathrm{Na}$, with concentrations varying significantly between coalfields and between seams in the same field and even laterally within the same seam.

Concentration gradients of these inorganic elements are often observed within seams in the open cuts, particularly for $\mathrm{Na}$ levels near the tops of seams. Generally, but not always, levels of $\mathrm{NaCl}$ (and sometimes other elements) decrease with depth.

\subsection{Combustion process}

For each boiler unit, raw brown coal was delivered to one of eight coal mills to be pulverised and delivered to the boiler for combustion. The pulverised coal was then combusted in the furnace, with the lighter particles carried with the combustion gases, through the boiler passes and to the precipitators, where this ash was collected. A small amount of the ash (typically $<5 \%$ of input solids to the precipitator) passed through the precipitator and was emitted to atmosphere. The fraction of ash that is carried through to the precipitators is known as fly ash and is estimated to make up $80-90 \%$ of the ash in the boiler.

The remaining $10-20 \%$ of the ash was too heavy to be carried with the combustion gases and fell to the furnace hearth. This ash typically had a large particle size and complete combustion was not achieved, resulting in a high carbon content relative to the ash carried through to the precipitator. This fraction is known as furnace bottoms ash. Bottoms ash was treated (crushed) and recombined with the fly ash components and transported to the ash ponds, not a separate waste stream.

During the start-up of the unit, the boiler was run on brown coal briquettes which were sourced from the adjacent Morwell Power Station and briquette factory, which dried and compressed brown coal into briquettes. Several times in the lifespan of the plant, the start-up fuel of the units was changed to black coal, due to shortages of briquettes from the factory. However, as the boilers operated almost continuously, startup events only occurred periodically for each boiler following a boiler shutdown. Over a period of February 2011 to March 2017, the proportion of auxiliary fuel firing (briquettes or black coal) relative to brown coal was about $0.16 \%$, which was assumed for the life of the of Hazelwood Power Station. 
Due to the high carbon content in both the fly ash and furnace ash during start-up, the precipitators are generally not run due to fire and explosion risks. This further limits the amount of ash from the briquettes or black coal collected from the combustion process.

\subsection{Coal ash formation}

Based on the discussion above, it can be stated that a very high proportion (>99.8\%) of the solids entering the Hazelwood ash ponds would have originated from the Hazelwood mine coal combusted in the Hazelwood boilers.

Therefore, if the coal entering the boiler plant has consistent properties it can be expected that the ash exiting the boiler plant will also have consistent ash properties. The exception could be the level of unburnt carbon which would be dependent on factors such as milling efficiency and combustion conditions. It should also be noted that the carbon content of bottoms ash (in the order of $40 \%$ dry basis) will be significantly higher than for precipitator ash (in the order of $10 \%$ dry basis).

The formation of ash from the combustion of brown coal is influenced by the type and concentration of the ash forming constituents as well as the combustion conditions (e.g. temperature, heating rate, oxygen level). The inorganic components of coal behave differently from the mineral components in the combustion process. The inorganics in brown coal are bound as the salts of carboxylic acids, and undergo complex reactions during the combustion process. The specific set of reactions that the minerals undergo are related to the temperature of the combustion process and whether this occurs in an oxidative or reductive environment.

Ash composition results reported for Victorian brown coal are typically based on ash produced in a laboratory muffle furnace at $815^{\circ} \mathrm{C}$ in a highly oxidising environment for which the inorganic products of combustion will be in their maximum oxidation state. In contrast, in a coal fired boiler the combustion process is rapid (almost instantaneous) and occurs at a higher temperature, which can lead to different species being present in the ash.

There could thus be some differences in some properties of brown coal ash reported in the literature (based on laboratory ash) and the properties of boiler ash. However, whilst the oxide species present in the ash may be different between the ash sourced from coal analysis and that produced by the station, the ratio of the key elements $\mathrm{Si}, \mathrm{Al}, \mathrm{Ca}, \mathrm{Fe}, \mathrm{Na}$ and $\mathrm{Mg}$ to each other are expected to be similar. Therefore, evaluating the consistency of the ash properties of the feed coal to the boilers based on these key elements is a reasonable approach to assessing the consistency and properties of the ash produced from combustion at Hazelwood. Such an approach is not as valid for more volatile components including $\mathrm{S}$ and $\mathrm{Cl}$ for which there can be significant differences between the feed coal and product ash and also between laboratory ash and power station ash.

The other important difference between laboratory furnace ash and power station ash compositions, is that the power station ash samples contain significant amounts of unburnt coal and/or char, particularly in the bottom ash where levels can often be very high (e.g. 40\%). The levels in the precipitator ash are lower (e.g. 10\%) but still significant. The level of carbon (char) in the ash is dependent on the type of coal (woody fractions) and the plant operating conditions. The level of char does not have an impact on the inorganic elements present in the ash.

\subsection{Coal ash deposition}

Prior to 2006 and the thickening plant and the HARA, coal ash collected from the precipitators was mixed with water and sent to the ash ponds for disposal. Once per shift, the furnace hearths were ashed, where the furnace bottoms ash was manually raked from the hearth into a sluice trench, where it was washed into the ash pits. The ash slurry was then pumped to the four operating ash ponds (HAP1 to HAP4), where the ash settled out and the water was drained. The drained water contained the majority of the water soluble 
proportion of the solids exiting the boiler plant to the ash ponds. The drained water was generally reused for sluicing the ash from the plant.

In 2006, a thickening plant was installed to dewater the ash from the plant and enable this thickened ash to be returned directly to the mine, avoiding the ash ponds. After 2006, ash from the ash pits was directed to the ash thickening plant, where a flocculent was added to the ash slurry. The flocculent was dosed at a rate of $100 \mathrm{~g}$ per $\mathrm{t}$ using a $1 \%$ flocculent concentration. The flocculent used was a proprietary compound. The thickened ash, at a given solids concentration, was then pumped to the HARA in the Hazelwood mine. It is understood that only the thickened ash was disposed in the HARA. Clarified water from the thickening plant was sent to HAP1 for re-use in the plant. The ash pond layout is shown in Figure 2 with the green ponds noted as rehabilitated and the yellow ponds requiring rehabilitation.

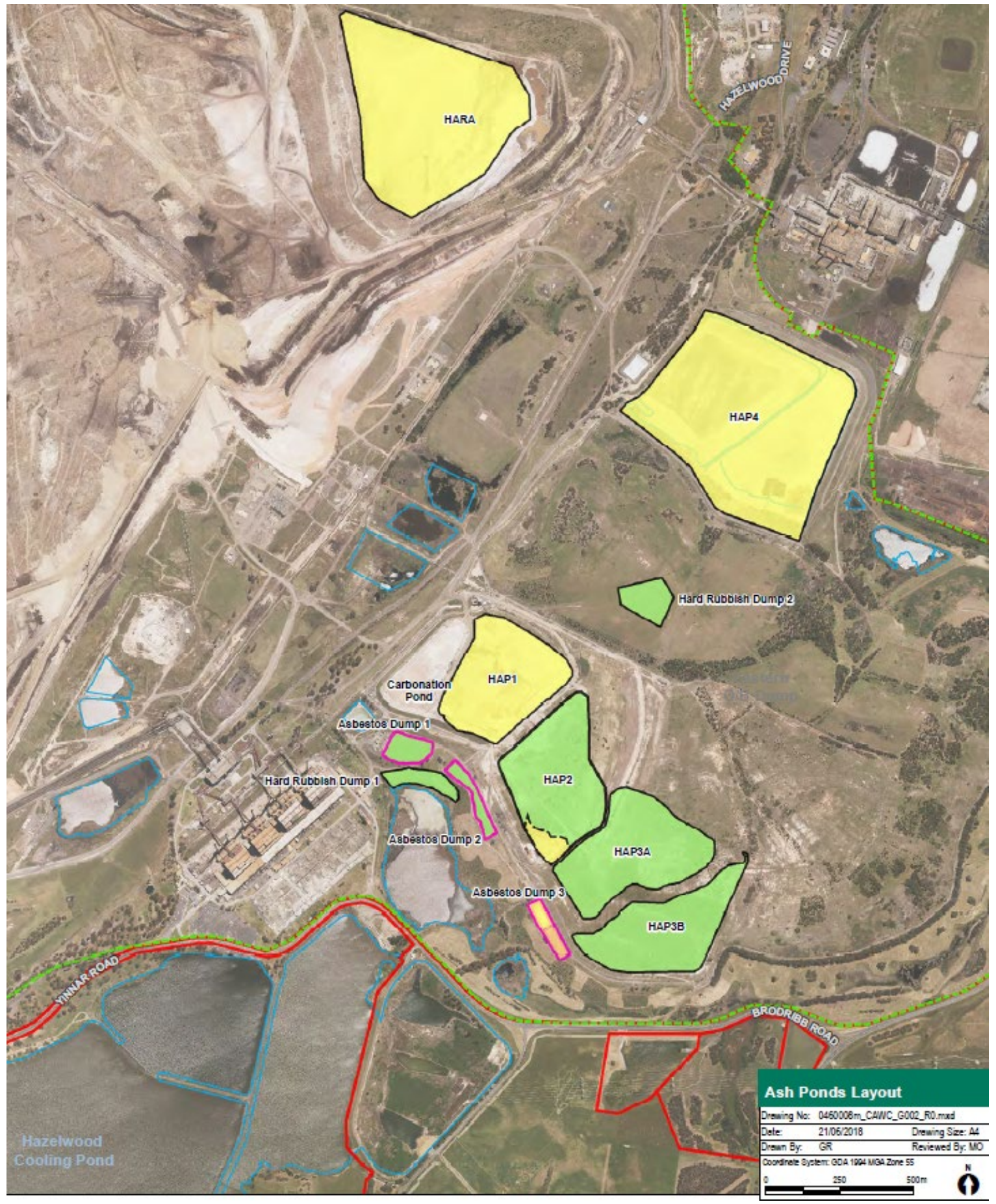

Figure 2 Hazelwood Ash Ponds layout 


\section{Coal ash sampling}

\subsection{Coal ash volumes}

As indicated, licenced landfills (ash ponds) at the former Hazelwood Power Complex that are to be capped and that contain coal ash are the HARA, HAP1, HAP2 remnant and HAP4. Table 1 presents the volumes associated with each ash pond based on a July 2016 survey.

Table 1 Coal ash volumes to be categorised

\begin{tabular}{lcccc}
\hline Ash pond & $\begin{array}{c}\text { Maximum } \\
\text { capacity }\left(\mathbf{m}^{3}\right)\end{array}$ & $\begin{array}{c}\text { Volume } \\
\text { utilised }\left(\mathbf{m}^{3}\right)\end{array}$ & $\begin{array}{c}\text { Volume } \\
\text { remaining }\left(\mathbf{m}^{3}\right)\end{array}$ & $\begin{array}{c}\text { \% filled } \\
\text { with ash }\end{array}$ \\
\hline HAP1 & 401,200 & 341,780 & 59,420 & 85 \\
HAP2 remnant & 10,800 & 7,045 & 3,755 & 65 \\
HAP4 & $5,930,361$ & 773,394 & $5,156,967$ & 13 \\
HARA & $9,100,000$ & $1,344,797$ & $7,755,203$ & 15 \\
\hline
\end{tabular}

\subsection{Initial sampling results}

To appreciate the temporal changes in ash composition, categorisation of the coal ash waste generated at Hazelwood was undertaken by comparing historical ash composition data provided by ENGIE Australia Pty Ltd (ENGIE) against the IWRG 631 Solid Industrial Waste Hazard Categorisation and Management Guidelines (EPA Victoria 2009a).

The historical samples were reported to be predominantly characterised as leached ash, which is described as having been deposited and leached from between 6 and 12 months. Samples considered were from HAP1, HAP3, HAP4 and the HARA.

Comparison of the historical analytical data with the IWRG 631 (EPA Victoria 2009a) total concentration and leachability solid industrial waste hazard categorisation thresholds indicate no exceedances of analysed total metal concentrations in all samples for the limited analytes assessed (not the full IWRG 631 list). The samples analysed from leached ash did not exceed the leachability criteria for industrial waste. Leachable boron concentrations were an order of magnitude lower than leachability criteria for industrial waste and leachable selenium concentrations were one to two orders of magnitude lower in all samples.

In September 2017, ENGIE undertook additional preliminary sampling of the ash within each ash pond for the complete suite of compounds as outlined in EPA Publication IWRG 631 (EPA Victoria 2009a) to provide an indication of the waste categorisation. Each sample was analysed for total concentration and for total leachability concentration, consistent with EPA Publication IWRG 631 (EPA Victoria 2009a). Table 2 presents a tabulated summary of results of the preliminary sampling. 
Table 2 Coal ash categorisation

\begin{tabular}{lcccc}
\hline $\begin{array}{l}\text { Sample location } \\
\text { (ash pond) }\end{array}$ & $\begin{array}{c}\text { Number of } \\
\text { samples }\end{array}$ & $\begin{array}{c}\text { Provisional IWRG 631* } \\
\text { category (total concentration } \\
\text { and ASLP concentration) }\end{array}$ & $\begin{array}{c}\text { Sample with } \\
\mathbf{p H ~ > 9}\end{array}$ & Sample pH \\
\hline HAP1 & 4 & Industrial waste & Sample 3 & 11.7 \\
- & - & Industrial waste & Sample 4 & 11.3 \\
HAP2 & 3 & Industrial waste & Sample 1 & 9.5 \\
remnant & & Industrial waste & Sample 2 & 9.4 \\
HAP4 & 4 & Industrial waste & Sample 1 & 10.4 \\
- & - & Industrial waste & Sample 3 & 11.1 \\
- & - & Industrial waste & Sample 4 & 9.1 \\
\hline HARA & 4 & Industrial waste & Sample 1 & 10.5 \\
- & - & Industrial waste & Sample 2 & 11.5 \\
\hline- & - & Industrial waste & Sample 3 & 10.8 \\
\hline- & - & Industrial waste & Sample 4 & 9.5 \\
\hline * - EPA Victoria 2009a; IWRG - Industrial Waste Resource Guidelines; ASLP - Australian Standard Leaching Procedure; \\
HAP-Hazelwood Ash Ponds; HARA - Hazelwood Ash Retention Area. & &
\end{tabular}

The results indicated that based on the preliminary dataset, with the exception of $\mathrm{pH}$, the ash would typically be categorised as industrial waste. These results are very similar to the results from the historical testing 10 years ago suggesting consistence of results on the temporal scale.

EPA indicated that an exemption to the guidelines would be allowed for $\mathrm{pH}$, should additional testing demonstrate that all other analytes remain within the Industrial Waste range (IWRG 631, EPA Victoria 2009a).

\subsection{Statistical approach to estimating sample numbers}

Sampling in strict accordance with IWRG 702 (EPA Victoria 2009b) required a volumetric based sampling approach ( 1 sample $/ 250 \mathrm{~m}^{3}$ ), however in this case where a large volume of coal ash has been deposited since the 1960s, the number of samples required would be prohibitive and potentially unnecessary given the uniform process being undertaken at Hazelwood and thus the anticipated homogenous nature of the coal ash deposits.

The preliminary round of samples, 15 in total, (the population), provided some baseline data of sample variability (coefficient of variance). Using the sample variability for each analyte, Environmental Resources Management Australia Pty Ltd (ERM) applied a statistical approach to calculate how many additional samples would be required to predict the mean concentration of each analyte, with a high level of confidence that the true result is less than the industrial waste guideline value in IWRG 631 (EPA Victoria 2009a).

ERM determined that the student's t-distribution would allow for the best statistical analysis. This statistical method is a standard, statistical equation used for precision calculations for normally distributed populations. Equation 1 is presented here and accounts for four parameters:

- The sample size $(\mathrm{n})$.

- The variability of the population (s).

- The width of the desired confidence interval (d).

- The specified confidence level (a). 


$$
n=\frac{s^{2} t_{\alpha(2),(n-1)}^{2}}{d^{2}}
$$

Together, these parameters form a 'closed system' so that if three of the four parameters are known, the fourth can be calculated. In this approach, ERM has adopted an iterative procedure to determine the width of the confidence interval for different sample sizes, using the rearranged formula:

$$
d= \pm \frac{s \cdot t_{\alpha(2),(n-1)}}{\sqrt{n}}
$$

where:

$$
\begin{array}{ll}
\mathrm{n} & =\text { sample size } \\
\mathrm{s} & =\text { estimate of the population standard deviation } \\
\mathrm{s}^{2} & =\text { estimate of the population variance } \\
\mathrm{d} & =\text { the half width of the confidence interval } \\
1-\alpha & =\text { the confidence level of the confidence interval } \\
\mathrm{n}-1 & =\text { the degrees of freedom } \\
\mathrm{t} & =\text { two-tailed t-critical value, determined from a student's t-table }
\end{array}
$$

This statistical approach was used to then determine a point where an increased number of ash samples would not beneficially decrease the confidence interval (a point of diminishing returns). In order to create a standardised estimate of the variance across analytes with different means, the coefficient of variance (CV) was used. The CV is defined as the standard deviation divided by the mean.

$$
C V=\frac{s}{\mu}
$$

The data from the initial round of sampling provided a range of CVs which would be appropriate to use (i.e. the minimum and maximum CV of the analytes which showed detections). From this, if a fixed population mean $(\mu)$, was set, and an upper, lower and mid estimate for the population standard deviation can be calculated.

The half width of the confidence interval $(d)$ could then be plotted as a function of $n$ and $\mu$.

$$
d(n, \mu)=\frac{\mu \cdot C V_{\text {lower }, \text { mid,upper }} \cdot t_{\alpha(2),(n-1)}}{\sqrt{n}}
$$

where:

$$
\begin{aligned}
\mu \quad= & \text { fixed } \\
\mathrm{CV}= & \text { calculated from the initial sampling data } \\
\mathrm{t} \quad= & \text { calculated from the student's t-distribution, based on a 95\% confidence; therefore } \\
& \alpha=1-0.95=0.05 \\
\mathrm{n}= & \text { a variable }
\end{aligned}
$$

The width of the confidence interval was also standardised across analytes, by expressing it as a percentage of the mean (\% error); where percentage error is defined as:

$$
\% \text { error }=\frac{2 d(n, \mu)}{\mu} \times 100
$$

Plotting the '\% error' as a function of $(n)$, for each of the lower, mid and upper CVs from our data, provides a range of sample sizes for a specific confidence interval size as shown in Figures 3 and 4. 


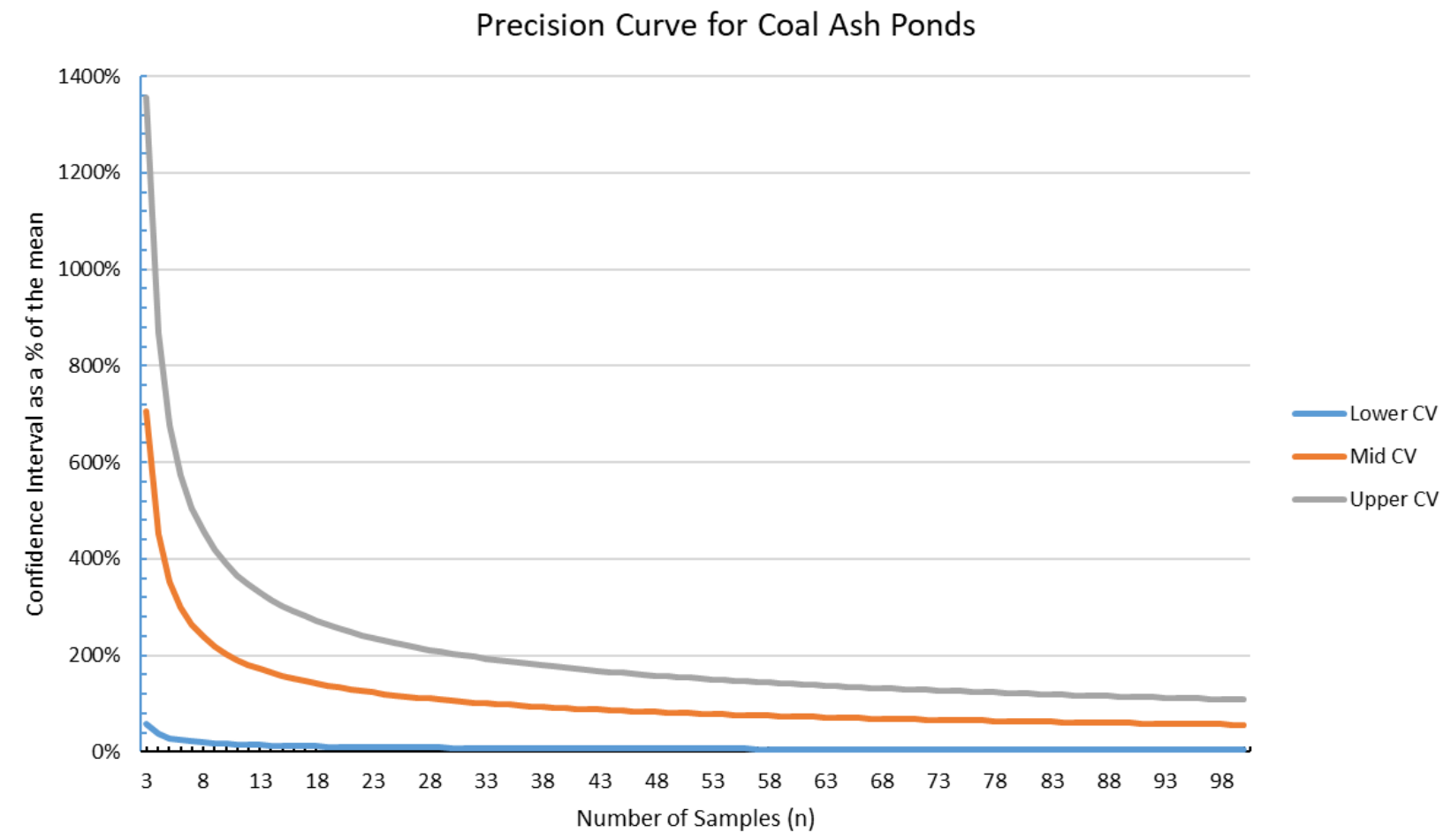

Figure 3 Precision curve for coal ash ponds - showing \% error as a function of $n$

Precision Curve for Coal Ash Ponds

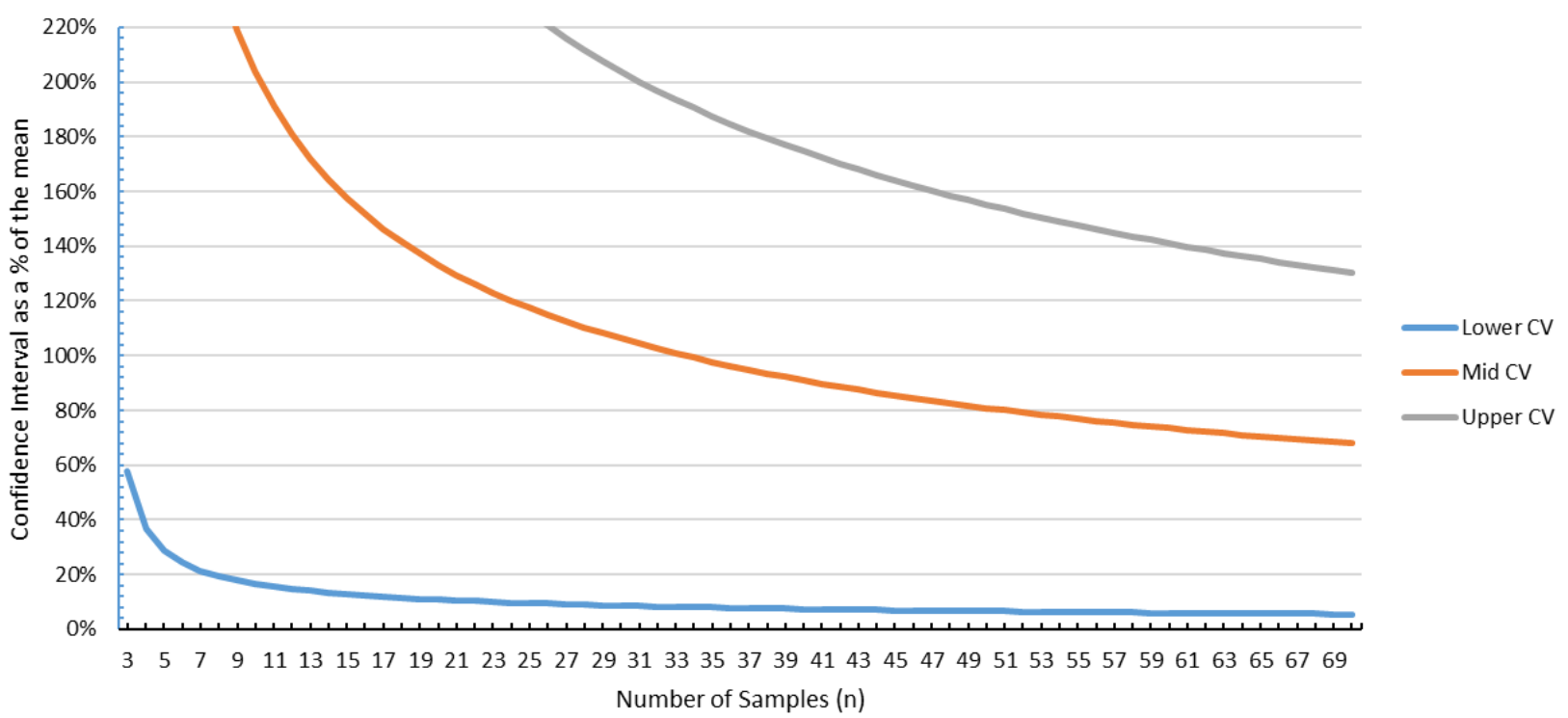

Figure $4 \quad$ Precision curve for coal ash ponds (zoomed vertical axis)

Based on the highest estimate for variation (upper CV), the point of diminishing returns occurs around $n=30$, with a $\%$ error $\approx 200 \%$. Therefore, a sample size greater than 30 samples would not considerably increase the precision of the mean estimate. Thus, for a sample size of 30 and for an analyte which shows a large variance, we can estimate the mean value of that analytes within the ash $(\mu)$ with a $95 \%$ confidence interval of $\pm 102 \%$ of the sample mean. For analytes which show less variation, a sample size of 30 would allow a mean estimation of the ash pond with higher precision. A $95 \%$ confidence interval with a width of $\pm 4 \%$ of the sample mean.

Table 3 shows a list of analytes which presented detections during the initial round of sampling (September 2017). The table includes calculations of the UCL assuming 30 samples and a corresponding confidence 
interval of $\pm 102 \%$ of the mean. This confidence interval is based on the highest variability found within the samples $(\mathrm{CV}=2.729)$, therefore overestimating the size of the confidence interval in most cases. That is, the actual precision of the mean estimate would be much higher.

Table 3 Coal ash preliminary analytical results

\begin{tabular}{|c|c|c|c|c|c|c|c|c|c|}
\hline Analyte & Units & Mean & $\begin{array}{l}\text { Actual } \\
\text { CV }\end{array}$ & $\begin{array}{l}\mathrm{CV} \\
\text { for } \mathrm{Cl}\end{array}$ & $\begin{array}{l}\mathrm{Cl}(\% \\
\text { error) }\end{array}$ & $\mathrm{Cl}$ & UCL & $\begin{array}{l}\text { Industrial } \\
\text { waste* }\end{array}$ & Cat C* \\
\hline $\begin{array}{l}\text { Total recoverable hydro- } \\
\text { carbons } \mathrm{C} 10-\mathrm{C} 36 \text { total }\end{array}$ & $\mathrm{mg} / \mathrm{kg}$ & 162 & 2.292 & 2.729 & 2.04 & 330.48 & 327.24 & 5,000 & 10,000 \\
\hline Total fluoride & $\mathrm{mg} / \mathrm{kg}$ & 25.47 & 0.59 & 2.729 & 2.04 & 51.96 & 51.45 & 10,000 & 10,000 \\
\hline Cr6+ & $\mathrm{mg} / \mathrm{kg}$ & 0.646 & 1.467 & 2.729 & 2.04 & 1.32 & 1.3 & 500 & 500 \\
\hline $\mathrm{Sb}$ & $\mathrm{mg} / \mathrm{kg}$ & 2.533 & 0.725 & 2.729 & 2.04 & 5.17 & 5.12 & 75 & 75 \\
\hline As & $\mathrm{mg} / \mathrm{kg}$ & 5.233 & 0.582 & 2.729 & 2.04 & 10.68 & 10.57 & 500 & 500 \\
\hline $\mathrm{Ba}$ & $\mathrm{mg} / \mathrm{kg}$ & 463.1 & 1.056 & 2.729 & 2.04 & 944.72 & 935.46 & 6,250 & 6,250 \\
\hline $\mathrm{Be}$ & $\mathrm{mg} / \mathrm{kg}$ & 0.953 & 0.74 & 2.729 & 2.04 & 1.94 & 1.93 & 100 & 100 \\
\hline B & $\mathrm{mg} / \mathrm{kg}$ & 86.83 & 0.472 & 2.729 & 2.04 & 177.13 & 175.4 & 15,000 & 15,000 \\
\hline Cd & $\mathrm{mg} / \mathrm{kg}$ & 0.597 & 1.055 & 2.729 & 2.04 & 1.22 & 1.21 & 100 & 100 \\
\hline $\mathrm{Cu}$ & $\mathrm{mg} / \mathrm{kg}$ & 23.77 & 1.714 & 2.729 & 2.04 & 48.49 & 48.02 & 5,000 & 5,000 \\
\hline $\mathrm{Pb}$ & $\mathrm{mg} / \mathrm{kg}$ & 16.27 & 2.124 & 2.729 & 2.04 & 33.19 & 32.87 & 1,500 & 1,500 \\
\hline Mo & $\mathrm{mg} / \mathrm{kg}$ & 2.9 & 2.593 & 2.729 & 2.04 & 5.92 & 5.86 & 1,000 & 1,000 \\
\hline $\mathrm{Ni}$ & $\mathrm{mg} / \mathrm{kg}$ & 83.33 & 0.703 & 2.729 & 2.04 & 169.99 & 168.33 & 3,000 & 3,000 \\
\hline Se & $\mathrm{mg} / \mathrm{kg}$ & 9.1 & 0.587 & 2.729 & 2.04 & 18.56 & 18.38 & 50 & 50 \\
\hline $\mathrm{Zn}$ & $\mathrm{mg} / \mathrm{kg}$ & 119.8 & 1.334 & 2.729 & 2.04 & 244.39 & 242 & 35,000 & 35,000 \\
\hline $\mathrm{Hg}$ & $\mathrm{mg} / \mathrm{kg}$ & 0.673 & 0.534 & 2.729 & 2.04 & 1.37 & 1.36 & 75 & 75 \\
\hline pH & $\mathrm{pH}$ units & 9.947 & 0.116 & 0.116 & 0.09 & 0.9 & 10.39 & & 9 \\
\hline
\end{tabular}

$\mathrm{CV}$ - coefficient of variance; $\mathrm{Cl}$ - confidence interval; $\mathrm{UCL}$ - upper confidence limit.

In summary, with 30 additional samples and assuming the new dataset has a similar CV as the preliminary dataset, ERM is $97.5 \%$ confident that the mean for each parameter will be less than the UCL quoted in Table 3. As each of the UCL's quoted in the table are significantly below the industrial waste levels then additional sampling to further reduce the error bars will only further lower the UCL value-which is of no benefit to making a waste categorisation.

Based on the previous statistical calculations, ERM proposed that 30 additional ash samples will be adequate to categorise the coal ash across the HARA, HAP1, HAP2 remnant and HAP4, and the number of samples from each location will be based on estimated deposited volume.

In discussion with EPA, it was requested that additional samples be taken on a precautionary basis and it was therefore agreed that 88 samples would be collected.

\subsection{Coal ash sampling and analysis}

ERM took 88 primary samples at a total of 35 investigation locations across the ash ponds. Specifically:

- 17 samples were taken at HAP1 from six locations (to a maximum depth of 4.5 metres below ground level (mbgl)). 
- 8 samples were taken at HAP2 remnant from three locations (to a maximum depth of $4.5 \mathrm{mbgl}$ ).

- 24 samples were taken at HAP4 from nine locations (to a maximum depth of $8.0 \mathrm{mbgl}$ ).

- 39 samples were taken at HARA from 17 locations (to a maximum depth of $4.0 \mathrm{mbgl}$ ).

Given the different stages of drying and stability and condition of each ash pond within the Hazelwood Power Complex, sampling investigation locations have been proposed in an effort to gain an understanding of the overall condition of the coal ash within each pond. This is considered to be sufficient to provide an indication of the general homogeneity of the ponds.

All samples were analysed for the following analytical suite (Table 4).

Table 4 Analytical suite

\begin{tabular}{|c|c|}
\hline Analytical suite & Sample frequency \\
\hline \multicolumn{2}{|c|}{$\begin{array}{l}\text { Metals (antimony, arsenic, boron, barium, beryllium, } \\
\text { cadmium, chromium, copper, molybdenum, mercury, } \\
\text { nickel, lead, selenium, silver, tin and zinc) }\end{array}$} \\
\hline Total recoverable hydrocarbons (TRH) & 88 primary samples \\
\hline Nitrate and nitrite & $\begin{array}{l}4 \text { inter-laboratory duplicates } \\
4 \text { intra-laboratory duplicates }\end{array}$ \\
\hline Chloride & \\
\hline \multicolumn{2}{|l|}{ Total fluoride } \\
\hline \multicolumn{2}{|l|}{$\mathrm{pH}$} \\
\hline IWRG 631 analytical suite (EPA Victoria 2009a) & 6 primary samples \\
\hline Benzene, toluene, ethylene, xylene (BTEX) & 1 trip blank sample \\
\hline
\end{tabular}

\subsubsection{HAP1}

A total of 17 primary coal ash samples were collected. Of the samples collected no exceedances of the IWRG 631 (EPA Victoria 2009a) criteria for industrial waste were reported. Detections were reported for most metals, most organics, and most total recoverable hydrocarbons (TRH) in sample HAP1-05 (4.0 mbgl), while HAP1-02 was reported only with detections for metals (including barium, boron, chromium, copper, lead, mercury, nickel, selenium and zinc) and organics, and no detections for TRHs. Analytical results for the ash sampled indicate all results are below the IWRG 631 (EPA Victoria 2009a) screening levels.

Samples from HAP1 had pH ranging from 9.3-12.3, indicating alkaline ash.

\subsubsection{HAP2 Remnant}

A total of eight primary coal ash samples were collected. With the exception of detections for TRH C10-C40 total, TPH C10-C36 total and lead, samples collected from HAP2 remnant were reported with concentrations considered to be similar to one another. Analytical results for the ash sampled indicate all results are below the IWRG 631 (EPA Victoria 2009a) screening levels.

All samples from HAP2 remnant, with the exception of HAP2-01_0.3 and HAP2-02_0.5, had a pH >9 and hence are considered alkaline.

\subsubsection{HAP4}

A total of 24 primary coal ash samples were collected. Data collected for the 27 samples varies slightly between each sample in the number of detections and the magnitude of detections for metals, organics, and 
TRHs. Analytical results for the ash sampled indicate all results are below the IWRG 631 (EPA Victoria 2009a) screening levels.

All samples from HAP4, with the exception of HAP4-01_1.5, had a pH $>9$ and hence are considered alkaline.

\subsubsection{HARA}

A total of 39 primary coal ash samples were collected. Data collected from the 39 samples shows similarity in the quality of the ash. Of the samples collected no analytes had exceedances of the IWRG 631 (EPA Victoria 2009a) screening level for industrial waste.

With the exception of one sample (HARA-01_1.5 with pH = 7.7), samples from the HARA had pH ranging from 10.1-12.3 and hence are considered alkaline $(\mathrm{pH}>9)$.

\subsection{Statistical summary table of coal ash data}

Further to comparing the analytical results against IWRG 631 (EPA Victoria 2009a) screening levels, a statistical assessment of the results was completed for analytes which showed detections. Seventeen analytes were assessed, including $\mathrm{pH}$, fluoride, hydrocarbons (C10-C36, C10-C10) and metals (antimony, arsenic, barium, beryllium, boron, cadmium, copper, lead, mercury, molybdenum, nickel, selenium and zinc). The statistical assessment was completed in ProUCL, and it included a statistical population of 32 to 98 samples. A summary of the results is presented in Table 5.

Table 5 Statistical summary of coal ash composition

\begin{tabular}{lcccccc}
\hline Analyte & Population & $\begin{array}{c}\text { Mean } \\
\text { (mg/kg) }\end{array}$ & $\begin{array}{c}\text { Standard } \\
\text { deviation }\end{array}$ & $\begin{array}{c}\text { Coefficient } \\
\text { of variance }\end{array}$ & $\begin{array}{c}\text { 95\% UCL } \\
\text { (mg/kg) }\end{array}$ & $\begin{array}{c}\text { IWRG 631* } \\
\text { IW TC (mg/kg) }\end{array}$ \\
\hline TRH C10-C36 total & 34 & 223.5 & 234.1 & 1.0 & 317.9 & 5,000 \\
TRH C10-C40 total & 32 & 250.9 & 258.0 & 1.0 & 0.0 & N/A \\
Total fluoride & 34 & 44.6 & 12.7 & 0.3 & 47.1 & 10,000 \\
Antimony, Sb & 98 & 5.1 & 0.5 & 0.1 & 5.2 & 75 \\
Arsenic, As & 98 & 2.8 & 0.9 & 0.3 & 3.3 & 500 \\
Barium, Ba & 98 & 352.6 & 238.8 & 0.7 & 400.7 & 6,250 \\
Beryllium, Be & 98 & 1.1 & 0.3 & 0.3 & 1.1 & 100 \\
Boron, B & 98 & 98.5 & 50.3 & 0.5 & 97.5 & 15,000 \\
Cadmium, Cd & 98 & 0.0 & 0.2 & 6.0 & 0.1 & 100 \\
Copper, Cu & 98 & 11.3 & 10.4 & 0.9 & 15.9 & 5,00 \\
Lead, Pb & 98 & 6.6 & 8.5 & 1.3 & 8.1 & 1,500 \\
Mercury & 98 & 0.6 & 0.6 & 1.1 & 0.7 & 75 \\
Molybdenum, Mo & 98 & 2.3 & 1.2 & 0.5 & 2.5 & 1,000 \\
Nickel, Ni & 98 & 60.8 & 33.4 & 0.5 & 66.4 & 3,000 \\
Selenium, Se & 98 & 7.1 & 4.7 & 0.7 & 7.7 & 50 \\
Zinc, Zn & 98 & 52.5 & 55.5 & 1.1 & 57.7 & 35,000 \\
pH (pH units) & 98 & 11.3 & 1.0 & 0.1 & 11.5 & N/A \\
\hline
\end{tabular}

UCL - upper confidence limit; IWRG - Industrial Waste Resource Guidelines; * - EPA Victoria 2009a; IW TC - industrial waste total concentrations; TRH - total recoverable hydrocarbons. 


\section{Conclusion}

The objective of the investigation was to assess the composition of coal ash to enable waste categorisation of the coal ash within the ash ponds and thus inform the rehabilitation capping design.

A high level desktop review of the consistency of Hazelwood coal and ash was undertaken by HRL based on information available from a range of previous projects performed for the Hazelwood Power Station. The review considered the movement of coal ash through the powerplant over the operational history, the composition of the input coal and resultant ash by reviewing historical datasets. The review undertaken by HRL concluded that the properties of the Latrobe Valley coals and thus the resultant combustion ash are consistent over extended time/operational history and that the coal combustion process is a well-controlled and continuous process. HRL did not identify any significant changes in the coal combustion process or downstream ashing process over time that would have had a significant impact on the coal ash composition. Overall, HRL concluded that the consistency of the coal properties over time and operational history combined with the consistency of the processes of combustion, ash transport and ash deposition it is highly likely that the ash deposited in the landfills at Hazelwood is largely homogeneous.

Taking a strict literal interpretation of the EPA Victoria sampling guidelines would result in 10,000 samples being required for the volume of ash being categorised. ERM proposed an alternative statistical approach based on preliminary coal ash sample results and demonstrated statistically that an additional 30 samples were required, assuming the new dataset has a similar CV as the preliminary dataset, for ERM to be $97.5 \%$ confident that the $95 \% \cup \mathrm{CL}_{\text {average }}$ for each parameter would be less than the EPA Victoria screening levels for industrial waste. EPA Victoria considered the proposal and was satisfied with 88 samples.

Excluding alkaline $\mathrm{pH}$, the results of the coal ash sampling investigation reported that total concentrations and leachability of all analytes were below IWRG 631 (EPA Victoria 2009a) criteria for 'industrial waste'. The results reported in the sampling program are consistent with historical sampling results demonstrating a high degree of homogeneity in the coal ash. The EPA therefore agreed with the proposed classification and made a determination that the coal ash could be categorised as 'industrial waste' and therefore requires a CCL (or equivalent) only without a geomembrane.

\section{Acknowledgement}

The authors wish to acknowledge all the workers at Hazelwood Power Station who have worked on the site over the many decades of operations as a critical electrical generator for the State of Victoria and especially all those who battled the Hazelwood mine fire in February 2014 which burnt for 45 continuous days.

\section{References}

Environment Protection Authority (EPA) Victoria, 2009a, Industrial Waste Resource Guidelines, Solid Industrial Waste Hazard Categorisation and Management, Publication IWRG 631, September 2009.

Environment Protection Authority (EPA) Victoria, 2009b, Industrial Waste Resource Guidelines, Soil Sampling, Publication IWRG 702, June 2009.

Environment Protection Authority (EPA) Victoria, 2015, Best Practice Environmental Management (BPEM), Siting, Design, Operation and Rehabilitation of Landfills, Publication 788.3, August 2015. 
